\title{
Identity and distribution of the Silesian minority in Poland
}

\begin{abstract}
According to the National Census of Population and Housing 2011, Silesians are the second largest nationality in Poland. Nevertheless, Silesian nationality is not recognised under Polish law. In this paper, the main aspects of the identity of the Silesian people are discussed. Research was carried out using questionnaire-based interviews in ten municipalities in the Silesian Voivodeship, characterised by the greatest share of Silesians. The ethnic identity of Silesians is complex - more than half of the respondents declared dual nationality. Most of the respondents demand the recognition of the Silesian ethnolect as a regional language, and consequently, its inclusion as a school subject in Upper Silesia. The postulate of establishing autonomy is popular, with a model of the Silesian Voivodeship from the period of interwar Poland.
\end{abstract}

Keywords

Minority $•$ nationality $\bullet$ identity $\cdot$ Silesians $•$ Upper Silesia $\bullet$ census

(C) University of Warsaw - Faculty of Geography and Regional Studies

\section{Patryk Orlewsk}

Department of Political and Historical

Geography and Regional Studies,

University of Lodz, Łódź, Poland

e-mail: orlewski.patryk@gmail.com

Received: 10 June 2018

Accepted: 27 December 2018
Introduction

There have been many discussions about the formal classification of Silesians. Sometimes they are considered as an ethnic minority, while other sources treat them as a Polish regional group (Komisja Wspólna Rządu i Mniejszości Narodowych i Etnicznych 2014; Gostkiewicz 2016). In this paper, they are considered as a nationality, because in the Polish censuses of 2002 and 2011, people had the possibility of such self-identification (GUS 2003, 2015). According to Statistics Poland (GUS 2015) nationality is a declared (based on subjective feeling) individual feature of the person, which expresses their emotional, cultural or genealogical relationship (due to the origin of parents) with a specific nation. However, not all nationalities declared in the censuses are recognised under Polish law. According to the Act of 6 January 2005 on national and ethnic minorities and on the regional languages, both ethnic and national minorities are characterised as those living on the territory of Poland for at least 100 years and having historical awareness about their community. Moreover, they need to be different from other citizens in terms of language, culture or tradition, and striving to preserve them. Nonetheless, a national minority has to identify itself with the nation organised in its own state (e.g. Germans, Jews, Russians), which is not the condition for ethnic minorities (e.g. Tatars, the Roma). In the above mentioned act, Silesians are not considered as a minority (Act 2005). Thus, one of the aims of this study is to answer the following questions: who, formally speaking, are the Silesians, what is their identity, and how should they be legally classified? Moreover, in the article, their distribution is analysed.

The identity of Silesians has been studied mostly since 1989, after the start of the democratisation process and extension of civil liberties in Poland. Previous publications dealt more with the German minority inhabiting the area of Upper Silesia (Nowakowski
1957; Misztal 1984). Gerlich (1994) and Kłosek (1995) conducted one of the first studies on Silesian identity in Poland. Other studies were focused more on the aspects of Upper Silesian regionalism (Wanatowicz 1995) and Upper Silesia as a borderland region (Szczepański 1999; Gładkiewicz 2012). After the publication of the results of the Polish census of 2002, several publications on the existence of Silesian nationality appeared (e.g. Wanatowicz 2004). Some authors dealt with the issue of the existence of the Silesian nationality (Faruga 2004; Nijakowski 2004; Jerczyński 2006), while others focused more on the political aspects of recognising Silesian identity (e.g. Janicki 2009).

Besides Polish research, Silesian issues were also discussed in German and Czech publications. Despite a Silesian minority in the Czech Republic that consists of only 12,231 people $(0.1 \%$ of total population) (Czech Statistical Office 2014), their identity had been studied by several authors. These studies allowed the mapping of geographical and historical aspects of the regional identity (Odehnal \& Šerý 2012, Vaishar \& Zapletalová 2016, Siwek 2006, 2017), as well as showing inter-ethnic relations in Czech Silesia (Šrajerová 2017). Moreover, Silesian identity has often been studied in the Czech-Polish cooperation (e.g. Siwek \& Kaňok 2000; Szczepański \& Janeczek 2006). Publications in German focused mainly on linguistic (Kocyba 2008, 2011) and cultural aspects (Joachimsthaler \& Schmitz 2004; Hałub \& Weber 2011) of Silesian distinctiveness.

\section{Historical background}

The identity of Silesian people began to intensively develop during the Spring of Nations in 1848. It was a period of awakening the national consciousness of many societies in Europe, and the impulse for the foundation of the Silesian League (Liga Śląska), whose members supported and represented the 
Table 1. Highest numbers of national and ethnic minorities in Poland (2011).

\begin{tabular}{|c|c|c|c|c|c|}
\hline \multirow{2}{*}{ Nationality } & \multicolumn{2}{|c|}{ 1st declared nationality } & \multirow{2}{*}{$\begin{array}{l}\text { 2nd declared } \\
\text { nationality }\end{array}$} & \multirow{2}{*}{ Total } & \multirow{2}{*}{$\begin{array}{l}\text { Total } \\
\text { co-declared with } \\
\text { Polish nationality }\end{array}$} \\
\hline & Total & As sole identity & & & \\
\hline Silesian & 435,750 & 375,635 & 410,969 & 846,719 & 430,798 \\
\hline Kashubian & 17,746 & 16,377 & 214,801 & 232,547 & 215,784 \\
\hline German & 74,464 & 44,549 & 73,350 & 147,814 & 63,847 \\
\hline Ukrainian & 38,387 & 27,630 & 12,613 & 51,001 & 20,797 \\
\hline Belarusian & 36,399 & 30,195 & 10,388 & 46,787 & 15,562 \\
\hline Roma & 12,560 & 9,899 & 4,489 & 17,049 & 7,036 \\
\hline Russian & 8,203 & 5,176 & 4,842 & 13,046 & 7,119 \\
\hline American & 1,239 & 813 & 10,600 & 11,838 & 10,811 \\
\hline Lemko & 7,086 & 5,612 & 3,445 & 10,531 & 3,621 \\
\hline English & 1,560 & 1,193 & 8,935 & 10,495 & 9,132 \\
\hline
\end{tabular}

Source: Struktura narodowo-etniczna, językowa i wyznaniowa ludności Polski. Narodowy Spis Powszechny Ludności i Mieszkań 2011 [The ethno-national, linguistic and religious structure of the Polish population. Polish Census of 2011], GUS 2015.

Silesian people (Jerczyński 2006). Shortly after World War I, the Union of Upper Silesians (Związek Górnoślązaków) was created. This was a radical organisation which aimed to establish the Free State of Upper Silesia (Wanatowicz 2006). Finally, as a result of the plebiscites and three Silesian uprisings (1919-1921), Upper Silesia was divided between Germany and Poland. In Poland, the newly created Silesian Voivodeship gained the status of autonomy (Czapliński 2002). Both in Poland and in Germany, the Silesians mostly identified with the Poles. This was confirmed in the censuses conducted from the mid-nineteenth century until World War II, which showed the dominance of the Polish language in the whole Upper Silesian region (Weber 1913; GUS 1937).

During World War II, German authorities encouraged the local population to register on the Volksliste (German People's List), which was compulsory in some parts of Upper Silesia (Czapliński 2002). After the war, when entire Upper Silesia became part of Poland, the communist authorities decided to eliminate German influence in the region. In the People's Republic of Poland, population transfers were organised, which resulted in settling Polish people from other regions (mainly Eastern Borderlands) in Upper Silesia, the so-called "Recovered Territories" (Kaszuba 2002). The new settlers and the Silesians treated each other with aloofness, due mainly to their different values and lifestyles (Szczepański 1999).

The return of democracy and a significant increase in civil liberties in 1989 contributed to the "awakening" of national and ethnic minorities in Poland (Gawrecki 2011). In Upper Silesia, some regional organisations were founded, such as the Silesian Autonomy Movement (RAŚ - Ruch Autonomii Śląska). The main aim of RAŚ is to gain autonomy for Upper Silesia (Ruch Autonomii Śląska, n.d.). The organisation is known for taking significant action to promote the ideas of Silesian nationality, among them The March for Autonomy held regularly since 2007. Moreover, RAŚ has run in local elections, gaining almost $8.5 \%$ of the votes in 2010 (Państwowa Komisja Wyborcza 2010) and 7.2\% in 2014 (Sejmik Województwa Śląskiego 2014).

The population and distribution of the Silesian minority in Poland, according to the census of 2011

According to the 2011 census, a total of 846,719 people ( $2.2 \%$ of Poland's population) declared Silesian nationality, which makes Silesians the second largest (after Polish) nationality in Poland. In total, 435,750 people declared Silesian as their first nationality (including 375,635 as their only one), whereas 430,798 people declared dual Silesian-Polish nationality (Table 1). The Silesians considerably outnumber other minorities in Poland (GUS 2015). The Silesian people form a community with a high territorial consistency. Often declared, dual identity is a typical feature of borderland populations in areas located at the crossroads of cultures, between more powerful neighbours, with political affiliation changing several times in the past (Szczepański 1999). Polish, Czech and German cultural influences played a large role in the history of Upper Silesia (Czapliński 2002). The phenomenon of a double national identity can also be seen in other border areas, such as the Podlasie region (Eastern Poland), where part of the population identifies with both Polish and Ukrainian/Belarusian nationality (Barwiński 2013).

The majority of Silesian people live in two voivodeships: Silesian and Opole. Among counties (powiats) the greatest population of Silesians live in the city of Katowice $(78,838$ people). The greatest share of the Silesian population is reported in the following counties: Rybnik (41.5\%), Mikołów (40.5\%), Bieruń-Lędziny (36.9\%), and cities: Piekary Śląskie (36.5\%) and Ruda Śląska (35.8\%) (Fig. 1) (Stowarzyszenie Osób Narodowości Śląskiej 2013).

\section{Methods and study area}

The research was carried out on the basis of questionnaire interviews conducted from 18 September to 26 October 2013. Besides closed questions, the respondents had to answer some open questions, where they had the possibility of expressing their opinion, which led to frequent discussions with the researcher. The relationship between respondents and researcher is very important for detailed and honest answers, and eventually, for reliable results (Geertz 2000; Sobczyński 2012). The research sample consisted of a total of 120 people in 10 municipalities (gminas) in the Silesian Voivodeship: Kobiór, Wyry, Piekary Śląskie, Radzionków, Piekary Śląskie, Ruda Śląska and Chorzów (Fig. 2).

The selection of municipalities was based on the 2002 census in Poland, since data for municipalities based on the 2011 census were not available. Six municipalities with the highest percentage of people who declared Silesian nationality were chosen: Kobiór, 


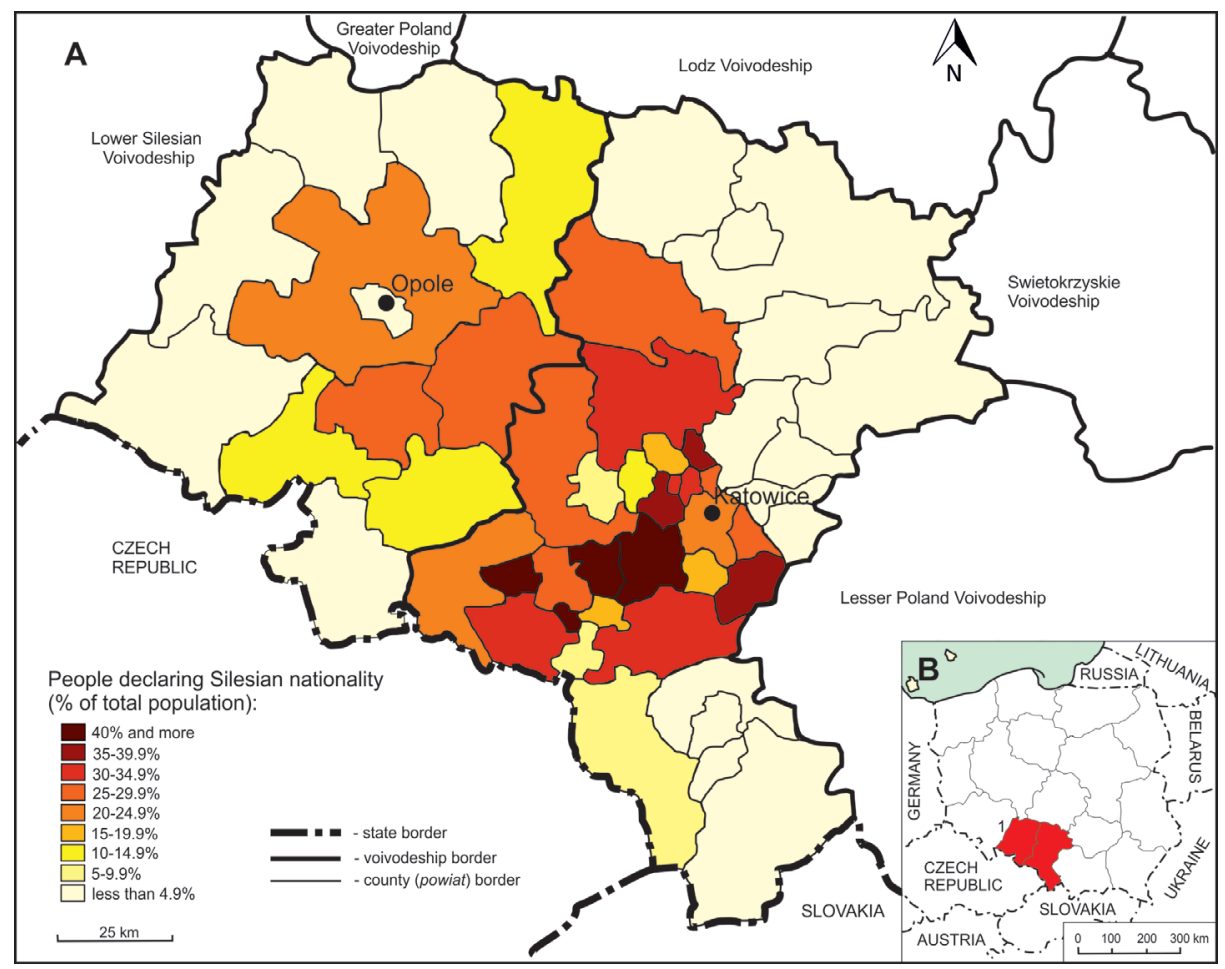

Fig. 1. A The percentage distribution of people declaring Silesian nationality according to the National Census of Population and Housing 2011; B - Opole and Silesian Voivodeships (in red). Source: based on http://slonzoki.org/ [16.08.2018], modified

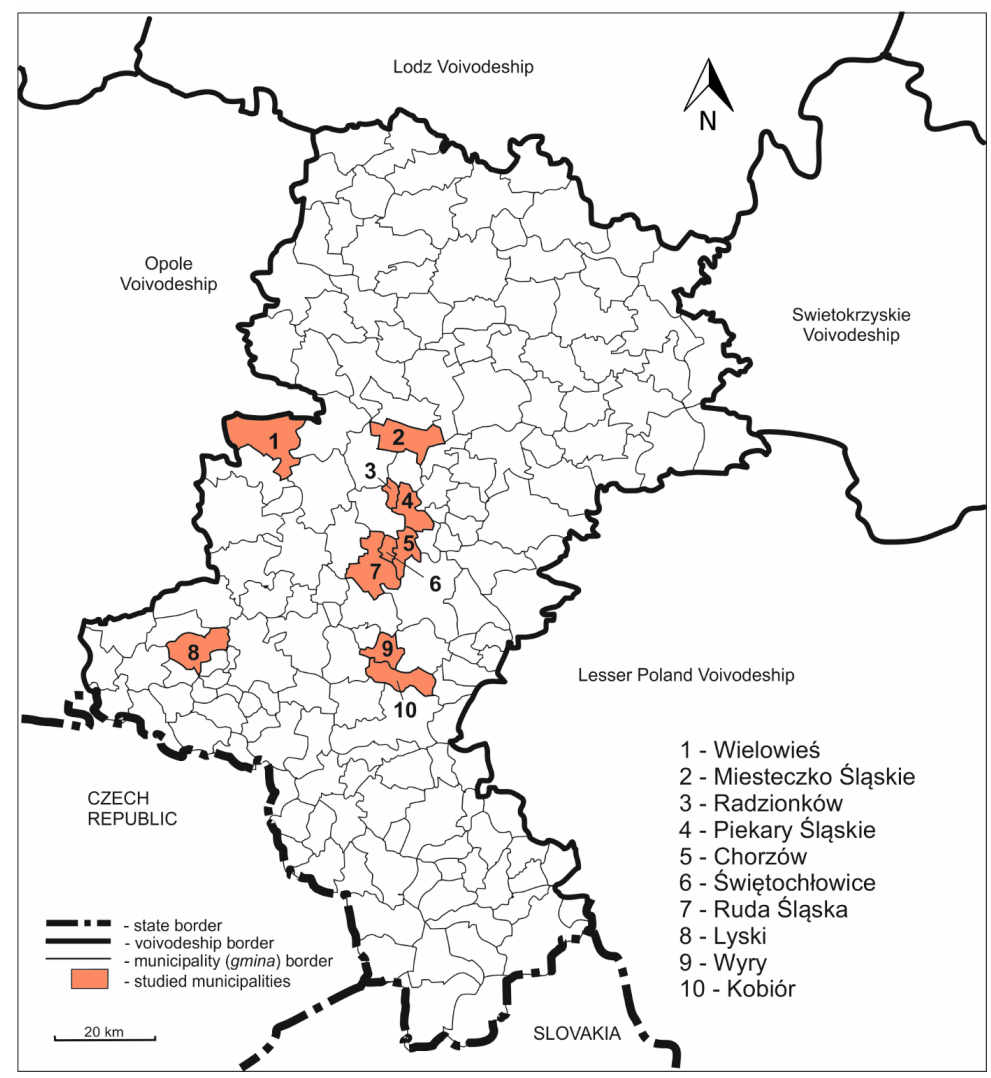

Fig. 2. Study area. Own elaboration 
Which nationality do you identify with?

A.
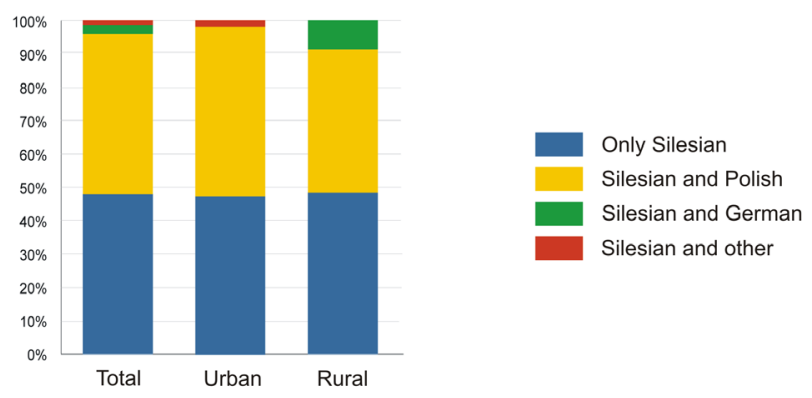

B.

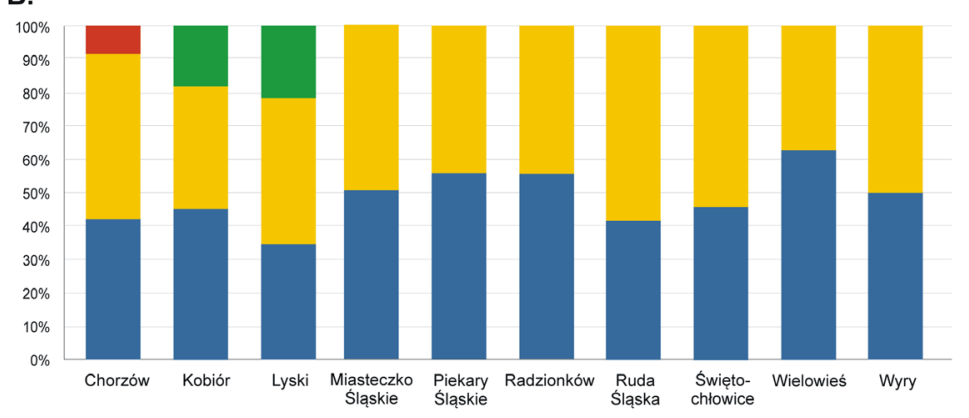

Fig. 3. Nationality declared by respondents: $A$ - by typology (total, urban/rural area); B - by studied municipality. Own elaboration

Wyry, Lyski, Miasteczko Śląskie, Wielowieś and Radzionków. All of them are located in the Silesian Voivodeship. In addition to these municipalities, four urban counties with the highest percentage of the population declaring the Silesian nationality were also selected: Piekary Śląskie, Ruda Śląska, Chorzów and Świętochłowice (Stowarzyszenie Osób Narodowości Śląskiej 2013).

Every questionnaire consisted of 25 questions. The selection of respondents was made on the basis of several characteristics. The most important feature was whether a person considered him - or herself a member of the Silesian nationality. The reason for this is that the research deals with the Silesian minority, not the entire population of the study area. A subjective feeling of belonging to a particular population group is the most important element of identity.

The age and gender structure, as well as the level of urbanisation of the Silesian Voivodeship (GUS 2013), were chosen as ideal for the surveys. Consequently, $17 \%$ of the interviews were conducted with people of pre-working age, $64 \%$ with people of working age and $19 \%$ with people of post-working age. Men and women were chosen to provide approximately half of the respondents. Another characteristic was the rural or urban character of the study area. According to Local Data Bank (GUS 2013), most of the population of the Silesian Voivodeship lives in cities, so $62 \%$ of the respondents were city dwellers.

\section{Results}

The research focused on several key features related to ethnic identity: sense of separateness, referring to a specific territory, own language and culture (Babiński 1998; Kocyba 2008, 2011). In the open question about the most important features of the Silesian identity, respondents most frequently indicated: Silesian language, traditions, strong attachment to religion and family.

The research has shown that a similar number of respondents declared double Silesian-Polish, and only Silesian identity
(Fig. 3A). Silesian-German national identity was declared only in two rural municipalities - Kobiór and Lyski. Respondents with only Silesian identity constituted an absolute majority in three municipalities: Wielowieś, Radzionków and Piekary Śląskie (Fig. 3B).

More than $2 / 3$ of the respondents indicated that their family members identified more as Silesians than Poles. As examples of modern expressions of Silesian tradition, respondents usually listed: the Silesian language, celebration days, cuisine, and work ethos. According to many respondents in Upper Silesia, Christmas and Saint Barbara's Day, the miners' holiday, are particularly celebrated. A respect for hard work is partially connected with the numerous people working in coal mines in Upper Silesia. Most Silesians are Roman Catholic. Participation in religious ceremonies is not only the fulfilment of a religious duty, but a very important part of everyday life for many members of this community. The vast majority of the Silesians also want to pass their customs on to their descendants.

One of the pillars of the Silesian identity is their ethnolect. Although the Silesian ethnolect is included in ISO 639-3 (International Organization for Standardization 2017), there is disagreement among Polish linguists about its classification. Miodek and Synowiec consider Silesian as a dialect of the Polish language (Siuciak 2012), whereas Tambor (2011) and Kamusella (2003) argue that Silesian should be classified as a regional language, such as Kashubian (Act 2005). Dubisz (1995) claimed that the Silesian ethnolect consists of not one, but several dialects. Due to the controversy about the classification of Silesian, in this paper the neutral term ethnolect is used (Majewicz 1989).

According to the 2011 census, over 527,377 people use Silesian in their homes (including 126,509 who speak only Silesian) (GUS 2015). The number of Polish citizens who speak Silesian does not coincide with the number of people who declared Silesian nationality. More than 300,000 of them do not use Silesian in everyday relations (Table 2). One of the reasons is 
MISCELLANEA GEOGRAPHICA - REGIONAL STUDIES ON DEVELOPMENT

Vol. 23 - No. 2 • 2019 • pp. 76-84 • ISSN: 2084-6118 • DOI: 10.2478/mgrsd-2019-0006

Table 2. Languages spoken at home in Poland (excluding Polish) (2011)

\begin{tabular}{|c|c|c|c|}
\hline $\begin{array}{c}\text { Language } \\
\text { spoken } \\
\text { at home }\end{array}$ & Total & $\begin{array}{c}\text { Number of people using: } \\
\text { only one } \\
\text { language }\end{array}$ & $\begin{array}{c}\text { more than one } \\
\text { language }\end{array}$ \\
\hline Silesian & $\mathbf{5 2 9 , 3 7 7}$ & $\mathbf{1 2 6 , 5 0 9}$ & $\mathbf{4 0 2 , 8 6 8}$ \\
\hline Kashubian & 108,140 & 3,802 & 104,338 \\
\hline English & 103,541 & 4,128 & 99,414 \\
\hline German & 96,461 & 9,738 & 86,723 \\
\hline Belarusian & 26,448 & 3,950 & 22,498 \\
\hline Ukrainian & 24,539 & 4,510 & 20,029 \\
\hline Russian & 19,805 & 1,136 & 18,669 \\
\hline Romani & 14,468 & 2,309 & 12,159 \\
\hline French & 10,677 & 640 & 10,037 \\
\hline Italian & 10,295 & 812 & 9,483 \\
\hline
\end{tabular}

Source: Struktura narodowo-etniczna, językowa i wyznaniowa ludności Polski. Narodowy Spis Powszechny Ludności i Mieszkań 2011 [ The ethno-national, linguistic and religious structure of the Polish population. Polish Census of 2011 ], GUS 2015. the post-war history: in communist Poland, the use of the Silesian ethnolect was frowned upon (Kaszuba 2002). Native Silesians were regarded as "uncertain elements" by communist authorities and they underwent an intensive Polonisation process (Simonides 2004).

The vast majority of respondents used the Silesian ethnolect, but only $3 / 5$ of them spoke Silesian in everyday life. These results are similar to those found in the 2011 census. In bigger cities (over 100,000 inhabitants), there was a weaker knowledge of the Silesian ethnolect. Moreover, it was rarely used by people under 25. Contrary to stereotypes, the frequency of speaking Silesian did not depend on education (Fig. 4A, B). Although most respondents claimed that their parents and siblings used Silesian constantly, only $1 / 3$ of them admitted that their children spoke Silesian often. It may suggest that Silesian is used less frequently among each subsequent generation. Respondents most often admitted that they learned Silesian from their parents and grandparents. However, Silesian is not often used between spouses. In many cases, native Silesians married people from outside Upper Silesia who did not speak Silesian.

Among the respondents, there was full agreement on the role of the Silesian ethnolect in their lives. The vast majority of respondents believed that Silesian should be included in the Act of 6 January 2005 on national and ethnic minorities and on the regional languages as a language (similar to Kashubian) and should be taught in schools in Upper Silesia (Fig. 5A, C). There were also many supporters of the idea of bilingual town signs (Fig. $5 B)$. Such a solution exists in many other places in Poland where the non-Polish population exceeds $20 \%$ of the total population: in Opole Voivodeship (German language), Pomeranian Voivodeship (Kashubian), Podlasie Voivodeship (Lithuanian and Belarusian) and Lesser Poland Voivodeship (Lemko) (Act 2005).

Do you know Silesian and use it in everyday relations?
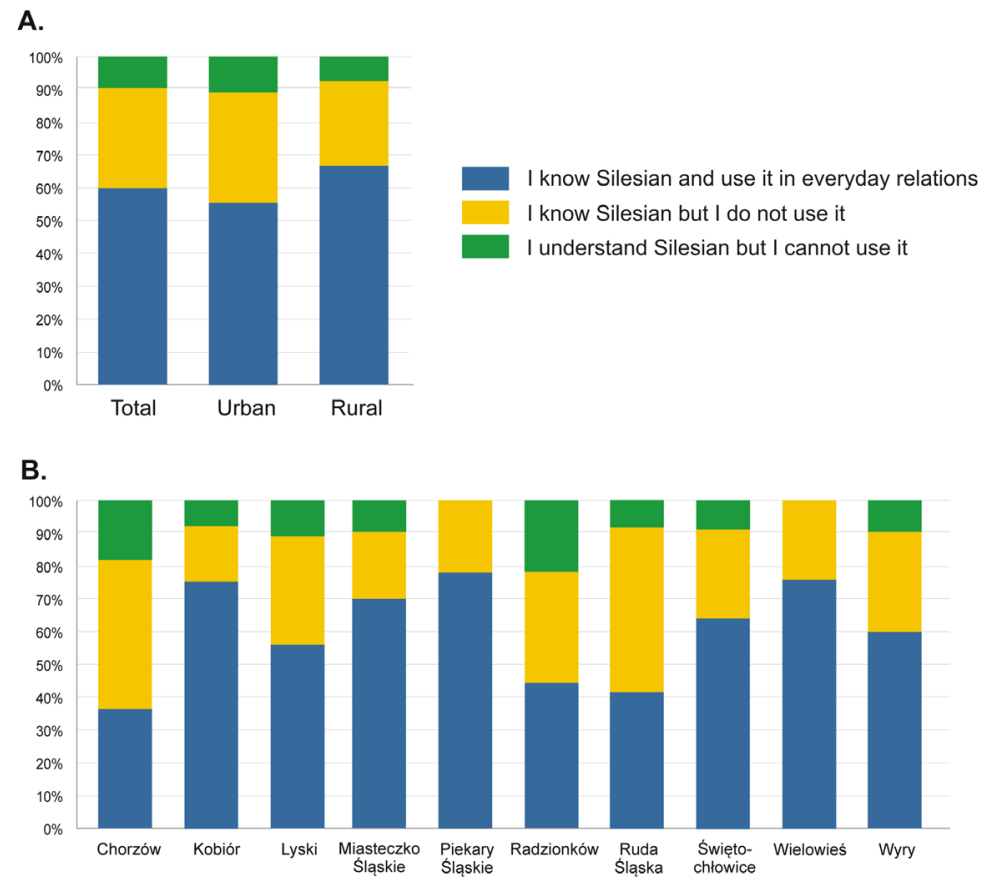

Fig. 4. Use of Silesian in everyday life by respondents: A - by typology (total, urban/rural area); B - by studied municipalities. Own elaboration 
Should Silesian be taught in schools in Upper Silesia?

A.

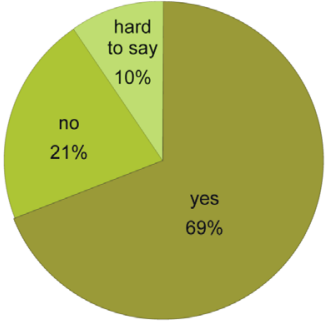

Should Silesian have status of regional language?

no

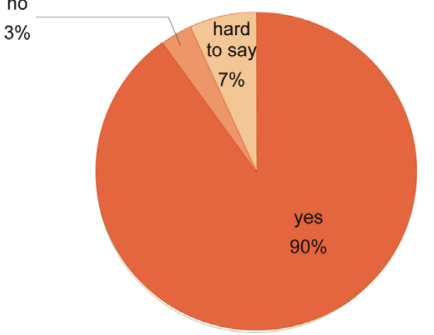

C.

Fig. 5. Opinion of respondents on Silesian ethnolect in schools, bilingual town signs, status of Silesian and autonomy of Upper Silesia. Own elaboration

Silesians have their territory, where they have been living for generations. The strong connection between the Silesians and the territory they inhabit, as well as a strong sense of individual identity were the reasons for including a question in the questionnaire interview about autonomy for Upper Silesia and about relations with other nationalities living in the region. Slightly more than half of the respondents supported the idea of Upper Silesian autonomy, whereas almost $1 / 3$ of them were against that idea (Fig. 5D).

According to the respondents, autonomous Upper Silesia should have its own budget and fiscal policy, as well as independent infrastructure, administration and healthcare. An important issue for many Silesians is the freedom to cultivate their culture. In their opinion, special attention should be given to regional education, which would allow students to learn more about the history of their region. Many respondents were aware of their history and often referred to interwar Poland, when the autonomous Silesian Voivodeship and the Silesian Parliament were functioning.

Besides Silesians, Upper Silesia is inhabited by Polish people who dominate in the region. Moreover, the German minority (mainly in Opole Voivodeship) is significant (Rykała 2014). In order to check the attitude of Silesians towards the co-inhabiting nationalities, respondents were asked to assess (on a scale from 1 to 5) relations between Silesians and Poles, as well as between Silesians and Germans. The relationship between Silesians and Germans got better scores: over $90 \%$ of respondents rated it between 3 and 5 . One-third of them defined relations with the German people as very good (Fig. 6). Among the reasons given for that were: no problems with members of the German minority, family working in Germany, and the overlapping of these two communities. However, some respondents believed that in Poland people describing themselves as Germans are in fact germanised Silesians. It should be noted that almost half of the respondents did not want to assess that relationship. Usually they explained it by the fact that they have never had any contact with anyone from the German minority.

Relations between Silesians and Poles were mostly rated between 3 and 5, but only 1 in 7 respondents assessed these relations as very good. On the other hand, less than $5 \%$ of respondents assessed these relations as very bad (Fig. 6). Generally, Silesians admitted that they had not been discriminated against by Poles. However, in their opinion, some negative stereotypes about Silesians exist in Poland. Silesians were especially prejudiced against the inhabitants of Warsaw. They blamed the Polish government for favouring the capital city at the expense of other regions, leading to economic stagnation and high unemployment.

\section{Conclusions}

The research indicates that Silesians differ from other population groups, although their identity is complex. About half of the respondents declared a double national identity. Similar results were to be found in the census conducted in Poland in 2011. Silesians commonly use their characteristic ethnolect, which is one of the most important elements of their identity. According to many of them, it should be classified as a regional language. The research also shows that the ethnolect is more rarely used by younger respondents, which overlaps with the tendency seen among the Silesian minority in the Czech Republic (Siwek \& Kaňok 2000). They are also enthusiastic about the idea of Silesian classes in schools and bilingual (Polish and Silesian) city names.

Silesian people want their distinctiveness as a minority to be sanctioned by Polish law. They are striving to preserve their culture through many events and organisations, as well as in everyday life. They have been living in the area of Upper Silesia 


\section{Rate on a scale of 1-5:}

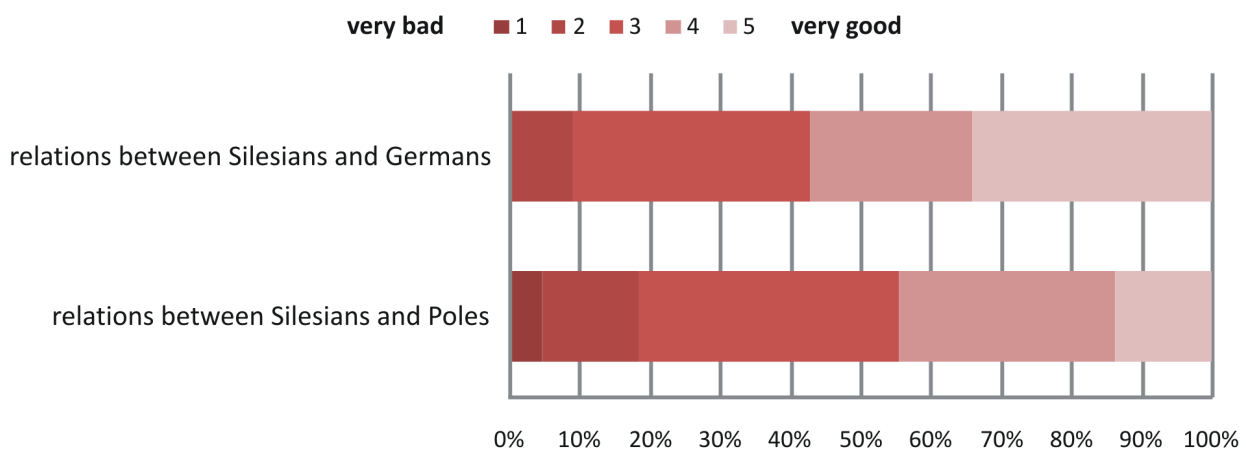

Fig. 6. Relations between Silesians and Germans, and between Silesians and Poles. Own elaboration

for hundreds of years, even though their citizenship has changed many times. Historical processes have undoubtedly influenced the national identity of the Silesians. The above features meet the conditions set out in the Act of 6 January 2005 on national and ethnic minorities and on the regional languages to be recognised as an ethnic minority.

The awakening of Silesian ethnic awareness is part of a wider trend of reviving regional movements in Europe, supported by the concept of "Europe of the regions" (Born 1998). Silesians are often compared with other minorities (e.g. Myśliwiec 2010), but the motives, aims and identities of many ethnic and national minorities are different and should be analysed in detail. The research shows that the ethnic identity of the Silesian minority needs further examination using a larger sample of respondents.

\section{References}

Act of 6 January 2005 on national and ethnic minorities and on the regional languages, Journal of Laws, No. 17, item 141.

Babiński, G 1998, Metodologiczne problemy badań etnicznych [Methodological problems of the ethnic studies], Nomos, Kraków.

Barwiński, M 2013, Geograficzno-polityczne uwarunkowania sytuacji Ukraińców, Łemków, Białorusinów i Litwinów w Polsce po 1944 roku [Geographical and political determinants of the situation of Ukrainians, Lemkos, Belarusians and Lithuanians in Poland after 1944], Wyd. Uniwersytetu Łódzkiego, Łódź.

Czapliński, M 2002, ,Dzieje Śląska od 1806 do 1945 roku [The History of Silesia 1806-1945]' in Historia Śląska [The History of Silesia], eds M Czapliński, E Kaszuba, G Wąs \& R Żerelik, Wyd. Uniwersytetu Wrocławskiego, Wrocław, pp. 278-466.

Czech Statistical Office 2014, Národnostní struktura obyvatel [Population by Nationality]. Available from: <https://www. czso.cz/documents/10180/20551765/170223-14.pdf>. [25 August 2018].

Dubisz, S 1995, Dialekty i gwary polskie [Polish Dialects and Gwaras], Wiedza Powszechna, Warszawa.

Faruga, A 2004, Czy Ślązacy są narodem? Przemilczana historia Górnego Śląska [Are Silesians a Nation? The Untold History of Upper Silesia], Rococo, Radzionków.

Gawrecki, D 2011, 'W poszukiwaniu górnośląskich tożsamości [In Search of Upper Silesian Identities]' in Historia Górnego Śląska. Polityka, gospodarka i kultura europejskiego regionu [The History of Upper Silesia. The Politics, Economy and Culture of the European Region], eds $\mathrm{J}$ Bahlcke, D Gawrecki, R Kaczmarek, Dom Współpracy PolskoNiemieckiej, Gliwice, pp. 57-72.

Geertz, C 2000, Available Light Anthropological Reflections on Philosophical Topics, Princeton University Press, Princeton.

Gerlich, MG 1994, ,O poczuciu przynależności narodowej i stosunku do "obcych”. Uwagi na marginesie badań nad świadomością narodową współczesnych Górnoślązaków [On the sense of national belonging and attitude towards 'strangers'. Remarks on the research on the national consciousness of contemporary Upper Silesians]', Polska Sztuka Ludowa. Konteksty, vol. 47, no. 1-2, pp. 130-135.

Gładkiewicz, R (ed.) 2012, Granice Śląska w interdyscyplinarnej perspektywie [The Borders of Silesia in an Interdisciplinary Perspective], Państwowy Instytut Nauki - Instytut Śląski, Opole.

Gostkiewicz, M 2016, ,Czy istnieje śląska mniejszość etniczna? Cztery argumenty za i cztery przeciw [Does Silesian ethnic minority exist? Four arguments for and four arguments against]', Gazeta Wyborcza25January.Availablefrom:<http:// wiadomosci.gazeta.pl/wiadomosci/1,114871,19529599,czyistnieje-slaska-mniejszosc-etniczna-cztery-argumenty-za. html>. [23 August 2018].

GUS 1937, Drugi powszechny spis ludności z dn. 9.XII.1931 r.: Mieszkania i gospodarstwa domowe. Ludność. Stosunki zawodowe: Województwo śląskie [Second General Census in Poland of 9 December 1931: Dwellings and households. Population, Employment: Silesian Voivodeship], Główny Urząd Statystyczny, Warszawa.

GUS 2003, Raport z wyników Narodowego Spisu Powszechnego Ludności i Mieszkań 2002 [Report on the results of the National Census of 2002], Available from: <http://stat.gov.pl/ spisy-powszechne/narodowe-spisy-powszechne/narodowyspis-powszechny-2002/raport-z-wynikow-narodowegospisu-powszechnego-ludnosci-i-mieszkan-2002,3,1.html>. [25 August 2018].

GUS 2013, Local Data Bank. Available from: <http://bdl.stat.gov. pl> [28 April 2018].

GUS 2015, Struktura narodowo-etniczna, językowa i wyznaniowa ludności Polski. Narodowy Spis Powszechny Ludności i Mieszkań 2011 [The ethno-national, linguistic and religious 
structure of the Polish population. Polish Census of 2011], Available from: <http://stat.gov.pl/spisy-powszechne/ nsp-2011/nsp-2011-wyniki/struktura-narodowo-etnicznajezykowa-i-wyznaniowa-ludnosci-polski-nsp-2011,22,1. html>. [28 April 2018].

Hałub, M \& Weber, M 2011, Mein Schlesien - meine Schlesier: Zugänge und Sichtweisen. Teil 2 (Schlesische Grenzgaenger) [My Silesia - my Silesians: Additions and Perspectives. Part 2 (Silesian Border Crossers)], Leipziger Univ.-Verl., Leipzig.

International Organization for Standardization 2017, ISO 639 Code Tables, Available from: <https://iso639-3.sil.org>. [25 August 2018].

Janicki, W 2009, 'Minority recognition in nation-states - the case of Silesians in Poland', in Chapters of Modern Human Geographical Thought, eds T Drobik \& M Sumberova, Cambridge Scholars Publishing, Cambridge, pp. 155-184.

Jerczyński, D 2006, Śląski ruch narodowy [Silesian National Movement], Narodowa Oficyna Śląska, Zabrze.

Joachimsthaler, J \& Schmitz, W 2004, Verhandlungen der Identität. Literatur und Kultur in Schlesien seit 1945 [Negotiations of Identity. Literature and Culture in Silesia since 1945], Eckhard Richter \& Co., Dresden.

Kamusella, T 2003, The Szlonzoks and their Language: Between Germany, Poland and Szlonzokian Nationalism, EUI Working Paper HEC No. 2003/1, European University Institute, Florence.

Kaszuba, E 2002, 'Dzieje Śląska po 1945 roku [The History of Silesia after 1945]' in Historia Śląska [The History of Silesia], eds M Czapliński, E Kaszuba, G Wąs \& R Żerelik, Wyd. Uniwersytetu Wrocławskiego, Wrocław, pp. 426-551.

Kłosek, E 1995, 'Meandry współczesnej identyfikacji etnicznej na Górnym Śląsku [Meanders of contemporary ethnic identification in Upper Silesia]' in Śląsk-etniczno-kulturowa wspólnota $i$ różnorodność [Silesia - ethno-cultural community and diversity], ed. B Bazielich, Sudety, Wrocław, pp. 123-137.

Kocyba, P 2008, 'Instrumentalizacja kontaktu językowego: Wasserpolnisch - gwara śląska - kreol górnośląski [Instrumentalization of language contact: Wasserpolnisch - Silesian Gwara - The Upper Silesian Creole]', Studia Germanica Gedanensia, no. 17, pp. 35-46.

Kocyba, P 2011, 'Oberschlesische Identitäten: Zwischen homogenen Sprach- und interferenten Sprechformen [Upper Silesian Identities: Between Homogeneous Language Forms and Interferent Speech Forms]', in Dialogische Begegnungen. Minderheiten-Mehrheiten aus hybridologischer Sicht [Dialogic Encounters. Minoritiesmajorities from a hybridological point of view], eds I Keller \& E Tschernokoschewa, Waxmann, Münster.

Komisja Wspólna Rządu i Mniejszości Narodowych i Etnicznych 2014, Opinia Komisji Wspólnej Rządu i Mniejszości Narodowych i Etnicznych dotycząca obywatelskiego projektu ustawy o zmianie ustawy o mniejszościach narodowych $i$ etnicznych oraz o języku regionalnym, a także niektórych innych ustaw (druk nr 2699). [Opinion of the Joint Commission of the Government and National and Ethnic Minorities regarding the civic draft act amending the Act on national and ethnic minorities and on the regional language, as well as some other acts (print no. 2699)]. Available from: <http:// mniejszosci.narodowe.mswia.gov.pl/>. [16 August 2018].

Majewicz, A 1989, Języki świata i ich klasyfikowanie [Languages of the World and Their Classification], PWN, Warszawa.

Misztal, J 1984, Weryfikacja narodowościowa na Śląsku Opolskim 1945-1950 [The national verification in Opole Silesia 1945-1950], Instytut Śląski, Opole.
Myśliwiec, M 2010, ,Czy Śląsk pójdzie drogą hiszpańskiej Katalonii? [ls Silesia going to go the way of Catalonia in Spain?] ,, Dziennik Zachodni 17 July. Available from: <http:/ dziennikzachodni.pl>. [28 April 2018].

Nijakowski, LM (ed.) 2004, Nadciągają Ślązacy. Czy istnieje narodowość śląska? [The Silesians are arriving: Does the Silesian Nationality Exist?], Scholar, Warszawa.

Nowakowski, S 1957, Adaptacja i integracja ludności na Śląsku Opolskim [Adaptation and integration of people in Opole Silesia], Instytut Zachodni, Poznań.

Odehnal, J \& Šerý, M 2012, 'Regional Identity and Its Reflection in Czech Human Geography', Dela no. 38, pp. 25-37.

Orlewski, P 2014, Mniejszość śląska w Polsce - geneza, rozmieszczenie, tożsamość. [Silesian minority in Poland - the genesis, distribution, identity] Master thesis, University of Lodz.

Państwowa Komisja Wyborcza 2010, Wybory Samorządowe 2010. [Local elections 2010] Available from: <http:// wybory2010.pkw.gov.pl>. [26 April 2018].

Ruch Autonomii Śląska n.d., Cele Ruchu Autonomii Śląska. [The objectives of Silesian Autonomy Movement] Available from: $<$ http://autonomia.pl/cele-ruchu-autonomii-slaska/>. [16 August 2018].

Rykała, A 2014, 'Mniejszości narodowe i etniczne w Polsce z perspektywy geografii politycznej [National and ethnic minorities in Poland from the perspective of political geography]', Acta Universitatis Lodziensis. Folia Geographica Socio-Oeconomica no. 17, pp. 63-111.

Sejmik Województwa Śląskiego 2014. Available from: <http:// www.wybory.slaskie.pl>. [26 April 2018].

Simonides, D 2004, ,Śląskie kłopoty z tożsamością [Silesian problems with identity]' in Nadciągają Ślązacy. Czy istnieje narodowość śląska? [The Silesians are arriving: Does the Silesian Nationality Exist?] ed. LM Nijakowski, Scholar, Warszawa, pp. 157-164.

Siuciak, M 2012, ,Czy w najbliższym czasie powstanie język śląski? [ls the creation of the Silesian language imminent?]', Poznańskie Studia Polonistyczne. Seria Językoznawcza, vol. 19 (39), pp. 31-44.

Siwek, T 2006, ,Czech Silesia: A Periphery of the Czech State', Europa XXI vol. 15, IGiPZ PAN, Warszawa, pp. 145-150.

Siwek, T 2017, 'Silesian Identity Across the Internal Border of the EU' in Borders in Central Europe After the Schengen Agreement eds T Havlíček, M Jeřábek \& J Dokoupil, Springer International Publishing, Cham, pp. 167-177.

Siwek, T \& Kaňok, J 2000, 'Mapping Silesian Identity in Czechia', Geographie - Sbornik České geografické společnosti, vol. 105, no. 2, pp. 190-200.

Sobczyński, M 2012, 'Interakcja "badacz-podmiot badania" w studiach nad mniejszościami w Polsce [Interaction between the researcher and the subject of research in minority studies in Poland] ', Studia z Geografii Politycznej i Historycznej, vol. 1, pp. 95-112.

Šrajerová, O 2017, 'Inter-ethnic relations in Silesia (From the results of sociological research arranged by the Silesian Institute of SZM in Opava)', Človek a spoločnost', vol. 20, no. 1, pp. 1-21.

Stowarzyszenie Osób Narodowości Śląskiej 2013, Narodowość śląska w powiatach wg GUS. [The Silesian nationality in the counties according to GUS] Available from: <http://slonzoki. org/2013/07/narodowosc-slaska-w-powiatach-wg-gus/>. [23 August 2018].

Szczepański, MS 1999, ,Region pogranicza kulturowego w perspektywie socjologicznej: przypadek Górnego Śląska [Cultural Borderland in Sociological Perspective: the Case of Upper Silesia] , in Studia Etnologiczne i Antropologiczne, vol. 2, pp. 161-180. 
Szczepański, MS \& Janeczek, J 2006, Dynamika śląskiej tożsamości [The Dynamics of Silesian Identity], Wyd. Uniwersytetu Śląskiego, Katowice.

Tambor, J 2011, Opinia merytoryczna na temat poselskiego projektu ustawy o zmianie Ustawy o mniejszościach narodowych $i$ etnicznych oraz o języku regionalnym, a także niektórych innych ustaw [Substantive opinion on the parliamentary draft act amending the Act on national and ethnic minorities and on the regional language, as well as on some other acts] Available from: < http://d.polskatimes. $\mathrm{pl} / \mathrm{k} / \mathrm{r} / 10 / 26 / \mathrm{fe} / 4 \mathrm{dd} 5396 \mathrm{ff} 3179$ z.pdf >. [16 August 2018]

Vaishar, A \& Zapletalová, J 2016, 'Regional identities of Czech historical lands', Hungarian Geographical Bulletin, vol. 65, no. 1 , pp. $15-25$

Wanatowicz, MW (ed.) 1995, Regionalizm a separatyzm - historia i współczesność [Regionalism and Separatism: History and the Presence], Wyd. Uniwersytetu Śląskiego, Katowice.

Wanatowicz, MW 2004, Od indyferentnej ludności do śląskiej narodowości? Postawy narodowe ludności autochtonicznej Górnego Śląska w latach 1945-2003 w świadomości społecznej [From the Nationally Indifferent Population to the Silesian Nationality? The Attitudes of the Autochthonous Population in Upper Silesia, 1945-2003], Wyd. Uniwersytetu Śląskiego, Katowice.

Wanatowicz, MW 2006, 'Tożsamość Ślaska w ogladzie historycznym [Identity of Silesia in Historical View] ' in Dynamika śląskiej tożsamości [The Dynamics of Silesian Identity], eds J Janeczek \& MS Szczepański, Wyd. Uniwersytetu Śląskiego, Katowice, pp. 35-55.

Weber, P 1913, Die Polen in Oberschlesien [The Poles in Upper Silesia], Eine statistische Untersuchung, Berlin. 